\title{
A STUDY ON INTERNET DEPENDENCY, SOCIAL ISOLATION AND PERSONALITY USING MAHALANOBIS DISTANCE
}

\author{
Sourav Chandra Gorain ${ }^{1}$, Anasuya Adhikari ${ }^{2}$, Dr. Birbal Saha ${ }^{3}$, \\ Dr. Subir Sen ${ }^{* 4}$ \\ ${ }^{1}$ Research Scholar, Department of Education, Sidho-Kanho-Birsha University, Purulia, WB, India \\ ${ }^{2}$ Research Scholar, Department of Education, Sidho-Kanho-Birsha University, Purulia, WB, India \\ ${ }^{3}$ Professor, Department of Education, Sidho-Kanho-Birsha University, Purulia, WB, India \\ ${ }^{4}$ HOD, Department of Education, Sidho-Kanho-Birsha University, Purulia, WB, India
}

"Corresponding Author: Dr. Subir Sen

Article DOI: https://doi.org/10.36713/epra8471 DOI No: 10.36713/epra8471

\begin{abstract}
With the advent of the globalised $21^{\text {st }}$ century, hominids have metamorphosed to the credence and dependence on the internet. From education to shopping, there is a cumbersome dependence on this media. Yet, this rapid chrysalis of the Internet is unfortunate enough on the other side, since it bears a large impact on the human personality, coercing people to isolate from the social world. The present study accords with comparison among different psychological aspects of postgraduate level students with the help of Mahalanobis Distance. Different variables viz. Internet Dependency, Social Isolation and five different factors of Personality are considered for this study. Different groups like science and arts, male and female are formed for this study. Seven dependent variables like Internet Dependency, Social Isolation, Extraversion, Agreeableness, Conscientiousness, Neuroticism and Openness are taken as a branch for two dichotomous independent variables sex (male and female) and stream (arts and science) and Mahalanobis Distances are measured. It can be wrapped up on this note with a conclusion that there are no significant differences in dynamical nature between male and female students and arts and science students.
\end{abstract}

KEYWORDS: Internet Dependency, Social Isolation, PG Level Students and Mahalanobis Distance.

\section{INTRODUCTION}

The internet is esteemed for a colossal number of assistance that it caters to the global world. The varied uses of internet in the domains of- education, shopping, finance, communication, blogging etc, has not only restricted our lives but has also made us sabotaged into it. This over dependence on internet is robbing one of the socio-cultural lives, inducing social isolation and depression. Hence, this dependence has proved to be providing compelling aftermath on the behavioral, cognition and emotional patterns, which originally foster from the biological and environmental factors.
Internet Dependency, Social Isolation and factors of Personality are very much akin to each other. The first two variables mentioned above are both related with cause-effect relationship and viceversa. The factors of personality have enormous influence on Internet Dependency and Social Isolation. Consistently, Dependency and Social Isolation might be the incitement of a changed Personality. So, it would be a better measure if one can measure the difference of these three dependent variables together for any set of independent variables.

Internet addiction disposes psychological as well as physiological conditions of the learners. 


\title{
EPRA International Journal of Research and Development (IJRD)
}

\author{
Volume: 6 | Issue: 9 | September 2021
}

- Peer Reviewed Journal

Several investigations show that there are existence of different types of complications and obstacles (Kendell, 1998; Orzark, (1999); Yen, et al. 2007; Morrison and Gore, 2010; Yao and Zhong, 2014; Kelley and Gruber, 2013; Kuss, et al. 2014).

Personal characteristics and internet use was studied by different scholars (Tosun and Lajunen, 2010; Swickeret al. (2002); Muscanell and Guadagno, 2011).

Social isolation and internet enslavement are consociated to one another. Studies of different researchers shows that internet fixation is a cardinal cause of social isolation and physical illness (Seif et al.2014; Izanloo and Goudarzi, 2011;Tiwari and Ruhela, 2012; Malviya et al., 2014; Goel, et al. 2013). Taylor et al. 1979; Thoits, 1995; Cohen et al. 1997; Pressman et al. 2005; Hawkleyet al. 2003; Heikkinen and Kauppinen, 2004).

In Mahalanobis Distance, a measure of divergence or distance between two groups is used in terms of multiple characteristics. P. Mahalanobis projected this measure (Mahalanobis, 1936). Several researchers used this distance (Xiang et al. 2008; Bedrick et al. 2000; Rubin, 1980; Cochran and Rubin, 1973; Marty et al. 2007; Rosenbaum, 2015; Diedrichsen et al., 2016; Cristani and Murino, 2018; Toma, 2019; Etherington, 2019; Imani, 2019) for their studies.

The latest studies show that the distance is handled in the field of education to correlate two sets of disparate variables to analyze the difference by measuring the Mahalanobis Distance (Ahmed et. al. 2020; Sen and Pal, 2020).

Present work is an investigation to dig and treasure out the difference in Internet Dependency, Social Isolation and five different factors of personality for two groups of learners. By t-test we can compare one set of data with another one set of data where only one column or one row is present [in matrix notation $A_{1 \times N}$ or $A_{N x 1}$ ] but by Mahalanobis Distance we can compare several set of data as a bunch with another several set of data as a bunch [in matrix notation $\left.\mathrm{A}_{\mathrm{MxN}}\right]$. This is an effective application of Mahalanobis Distance.

\section{OBJECTIVES}

Objectives of this study is to find out the difference in Internet Dependency, Social Isolation and five different factors of personality viz. Extraversion, Agreeableness, Conscientiousness, Neuroticism and Openness for two group of university level learners of Sidho-Kanho-Birsha University, Purulia, West Bengal, India. Three dependent variables are considered as a bunch and two such branches are compared. Mahalanobis distance is considered as a technique for analyzing the difference between scores obtained by different groups of learner which is considered for more generalized reflection of results.

\section{HYPOTHESES}

Following hypotheses are considered to investigate the significance among variables considered for the study as listed below:

$\mathrm{H}_{0} 1$ : There no significant difference between Arts and Science students in terms of scores obtained in Internet Dependency, Social Isolation and Extraversion.

$\mathrm{H}_{0}$ 2: There is no significant difference between Arts and Science students in terms of scores obtained in Internet Dependency, Social Isolation and Agreeableness.

$\mathrm{H}_{0} 3$ : There is no significant difference between Arts and Science students in terms of scores obtained in Internet Dependency, Social Isolation and Conscientiousness.

$\mathrm{H}_{0} 4$ : There is no significant difference between Arts and Science students in terms of scores obtained in Internet Dependency, Social Isolation and Neuroticism.

$\mathrm{H}_{0}$ 5: There is no significant difference between Arts and Science students in terms of scores obtained in Internet Dependency, Social Isolation and Openness.

$\mathrm{H}_{0} 6$ : There is no significant difference between Male and Female students in terms of scores obtained in Internet Dependency, Social Isolation and Extraversion.

$\mathrm{H}_{0} 7$ : There is no significant difference between Male and Female students in terms of scores obtained in Internet Dependency, Social Isolation and Agreeableness.

$\mathrm{H}_{0} 8$ : There is no significant difference between Male and Female students in terms of scores obtained in Internet Dependency, Social Isolation and Conscientiousness.

$\mathrm{H}_{0}$ 9: There is no significant difference between Male and Female students in terms of scores obtained in Internet Dependency, Social Isolation and Neuroticism.

$\mathrm{H}_{0}$ 10: There is no significant difference between Male and Female students in terms of scores obtained in Internet Dependency, Social Isolation and Openness.

$\mathrm{H}_{0}$ 11: There is no significant difference between Arts and Science students in terms of scores obtained in Internet Dependency, Social Isolation and Extraversion, Agreeableness, Conscientiousness, Neuroticism and Openness.

$\mathrm{H}_{0}$ 12: There is no significant difference between male students and female students in terms of scores obtained in Internet Dependency, Social Isolation, Extraversion, 


\section{EPRA International Journal of Research and Development (IJRD)}

Agreeableness,

Conscientiousness,

Neuroticism and Openness.

\section{SAMPLE}

250 PG students of Sidho-Kanho-Birsha University are taken as sample. The sample is collected by random sampling method.

\section{TOOLS}

Following tools are used for data collection.

- Internet Dependency Scale (IDS) by Mahanti et al. (2016)
- Social Isolation Scale (SIS) by Gorain et al. (2018)

- $\quad$ Big Five Inventory of Personality (BFI) by John et al. (1991)

\section{METHODOLOGY}

Following steps are followed for obtaining Mahalanobis Distance.

Step I: Formation of different groups of students Step II: Calculation of descriptive statistics Step III: Calculation of Mahalanobis Distance We can obtain Mahalanobis Distance with the help of following equation.

$$
\Delta^{2}=(X-Y)^{T} \Sigma^{-1}(X-Y)
$$

Where $X$ and $Y$ are column vectors of means and $\Sigma$ is pooled covariance matrix of two sets of data.

$$
\begin{gathered}
\text { Mahalanobis Distance }=\left[(\boldsymbol{X}-\boldsymbol{Y})^{T} \Sigma^{-1}(\boldsymbol{X}-\boldsymbol{Y})\right]^{\frac{1}{2}} \\
\text { Pooled Covariance Matrix } \\
\sum=\left[n_{1} \sum_{1}+n_{2} \sum_{2}\right] /\left(n_{1}+n_{2}\right)
\end{gathered}
$$

Where $\Sigma_{1}$ and $\Sigma_{2}$ be the Covariance Matrices, $n_{1}$ and $n_{2}$ be the sample size for first and second set respectively.

We can classify the calculated MD into three categories as follows:

a. $\mathrm{MD}<1$ : represents the distances are insignificant.

b. $1 \leq \mathrm{MD}<2$ : represents the distances are significant.

c. $\mathrm{MD} \geq 2$ : represents the distances are strongly significant.

Here distance significant means the difference between performances for two sets of variables is significant.

RESULTS AND DISCUSSIONS

Different sets of data are prepared for calculating the distance. Arrangement of data sets is listed as below:

\begin{tabular}{|c|c|c|c|c|c|}
\hline & $\begin{array}{c}\text { Internet } \\
\text { Dependency, } \\
\text { Social } \\
\text { Isolation } \\
\text { and } \\
\text { Extraversion }\end{array}$ & $\begin{array}{c}\text { Internet } \\
\text { Dependency, } \\
\text { Social Isolation } \\
\text { and } \\
\text { Agreeableness }\end{array}$ & $\begin{array}{c}\text { Internet } \\
\text { Dependency, Social } \\
\text { Isolation } \\
\text { and } \\
\text { Conscientiousness }\end{array}$ & $\begin{array}{c}\text { Internet } \\
\text { Dependency, } \\
\text { Social } \\
\text { Isolation } \\
\text { and } \\
\text { Neuroticism }\end{array}$ & $\begin{array}{c}\text { Internet } \\
\text { Dependency, } \\
\text { Social } \\
\text { Isolation } \\
\text { and } \\
\text { Openness }\end{array}$ \\
\hline Arts & Set 1 & Set 2 & Set 3 & Set 4 & Set 5 \\
\hline Science & Set 6 & Set 7 & Set 8 & Set 9 & Set 10 \\
\hline Male & Set 11 & Set 12 & Set 13 & Set 14 & Set 15 \\
\hline Female & Set 16 & Set 17 & Set 18 & Set 19 & Set 20 \\
\hline
\end{tabular}

Table 1: Arrangement of data for calculating Mahalanobis Distance 


\section{EPRA International Journal of Research and Development (IJRD)}

Volume: 6 | Issue: 9 | September 2021

- Peer Reviewed Journal

Initial requirements for Mahalanobis Distance like frequency and mean are listed in Table 2.

\begin{tabular}{|c|c|c|c|c|c|c|c|c|}
\hline & $\begin{array}{c}\text { Number } \\
\text { of } \\
\text { Students }\end{array}$ & $\begin{array}{c}\text { Internet } \\
\text { Addiction }\end{array}$ & $\begin{array}{c}\text { Social } \\
\text { Isolation }\end{array}$ & Extraversion & Agreeableness & Conscientiousness & Neuroticism & Openness \\
\hline Arts & 190 & 120.50 & 105.54 & 22.85 & 30.29 & 31.09 & 22.05 & 32.86 \\
\hline Science & 60 & 127.78 & 102.77 & 22.82 & 30.25 & 30.47 & 21.03 & 32.95 \\
\hline Male & 128 & 125.73 & 102.44 & 22.49 & 30.02 & 31.38 & 21.16 & 32.73 \\
\hline Female & 122 & 118.59 & 107.43 & 23.21 & 30.56 & 30.48 & 22.48 & 33.04 \\
\hline
\end{tabular}

Table 2: Descriptive statistics for different groups of students

\begin{tabular}{|c|c|c|c|c|c|}
\hline $\begin{array}{c}\text { Mahalanobis } \\
\text { Distance }\end{array}$ & $\begin{array}{c}\text { Internet } \\
\text { Dependency, } \\
\text { Social } \\
\text { Isolation } \\
\text { and } \\
\text { Extraversion }\end{array}$ & $\begin{array}{c}\text { Internet } \\
\text { Dependency, } \\
\text { Social Isolation } \\
\text { and } \\
\text { Agreeableness }\end{array}$ & $\begin{array}{c}\text { Internet } \\
\text { Dependency, Social } \\
\text { Isolation } \\
\text { and } \\
\text { Conscientiousness }\end{array}$ & $\begin{array}{c}\text { Internet } \\
\text { Dependency, } \\
\text { Social } \\
\text { Isolation } \\
\text { and } \\
\text { Neuroticism }\end{array}$ & $\begin{array}{c}\text { Internet } \\
\text { Dependency, } \\
\text { Social } \\
\text { Isolation } \\
\text { and Openness }\end{array}$ \\
\hline $\begin{array}{c}\text { Arts Vs } \\
\text { Science }\end{array}$ & 0.323767712 & 0.322658993 & 0.348734745 & 0.419142413 & 0.31486868 \\
\hline $\begin{array}{c}\text { Male Vs } \\
\text { Female }\end{array}$ & 0.536842498 & 0.443664262 & 0.462242145 & 0.510418582 & 0.427118895 \\
\hline
\end{tabular}

Table 3:Mahalanobis Distances for different group of students when three variables are considered

Mahalanobis Distances between two groups of students (Arts Vs Science and Male Vs Female) for three dependent variables are presented by Table 3 . All the distances by rule are insignificant.
Testing of $\mathrm{H}_{0} 1$ to $\mathrm{H}_{0} 10$ :

Here, all the Mahalanobis Distances are less than 1. So, there is no significant difference between Arts and Science students in terms of scores obtained in Internet Dependency, Social Isolation and Extraversion/ Agreeableness/ Conscientiousness/ Neuroticism/ Openness. So, all Null Hypotheses $\left(\mathrm{H}_{0} 1\right.$ to $\left.\mathrm{H}_{0} 10\right)$ are retained.

\begin{tabular}{|l|c|}
\hline $\begin{array}{l}\text { Mahalanobis } \\
\text { Distance }\end{array}$ & $\begin{array}{c}\text { Internet Dependency, Social Isolation, Extraversion, Agreeableness, } \\
\text { Conscientiousness, Neuroticism and Openness. }\end{array}$ \\
\hline $\begin{array}{l}\text { Arts Vs } \\
\text { Science }\end{array}$ & 0.5027 \\
\hline $\begin{array}{l}\text { Male Vs } \\
\text { Female }\end{array}$ & 0.7411 \\
\hline
\end{tabular}

Table 4:Mahalanobis Distances for different group of students when seven variables are considered.

Testing of $\mathrm{H}_{0} 11$ andH $\mathrm{H}_{0} 12$

Table 4 shows the Mahalanobis Distances between arts vs science students and male vs female students when seven dependent variables are considered as bunch of variables. As Mahalanobis Distances are less than 1 for the above mentioned hypotheses, there is no significant difference between the arts and science learners when seven variables are considered together. So, $\mathrm{H}_{0} 11$ is accepted. Similarly, significant difference is not found between male learners and female learners. As a result $\mathrm{H}_{0} 12$ is also accepted.

Although there are some dependent variablewise differences between male and female of PG level students but the dynamical nature of these two groups are not significantly different for internet addiction, social isolation and any one of personality trait. Similar result is also seen for internet addiction, social isolation and five of personality traits. Actually, majority of the sample are mainly come from a specific locality, Purulia district of West Bengal, India. Similarity of culture and social processes may be the basis of indifference.

Another important fact that there is no significant difference in dynamical nature between science and arts PG level students for internet addiction, social isolation and any one of personality trait. Similar result is also seen for internet addiction, 


\title{
SJIF Impact Factor 2021: 8.013| ISI I.F.Value:1.241| Journal DOI: 10.36713/epra2016 ISSN: 2455-7838(Online) \\ EPRA International Journal of Research and Development (IJRD)
}

\author{
Volume: 6 | Issue: 9 | September 2021
}

- Peer Reviewed Journal

social isolation and five of personality traits. This point is quite interesting because the pattern of the study for arts and science students are quite different but in the light of for internet addiction, social isolation and personality, when considered as a bunch, are quite similar.

\section{CONCLUSION}

Mahalanobis Distance is a powerful measure of distance for dynamical nature of a group of variables and it is represented by a single number. In present work each of the distances are non-significant which shows behaviour of each pair of groups are similar. Although there are differences in dependent variables, dynamical nature of the groups is independent of sex and stream.

\section{REFERENCES}

1. Ahmed, E. A., Banerjee, M., Sen, S. and Chatterjee, P. (2020). Application of Mahalanobis $\Delta^{2}$ on Achievement Tests on Mathematics: A Study on Higher Secondary Level Students. Indian Journal of Psychology and Education. Vol. 10(1), pp 36-40.

2. Bedrick, E. J., Lapidus, J. \& Powell,J. F. (2000). Estimating the Mahalanobis Distance fromMixed Continuous and Discrete Data, Biometrics, 56 (2), 394-401.

3. Cochran, W. G., and Rubin, D. B. (1973), "Controlling Bias in Observational Studies: AReview. Sankya Ser. A, 35, 417-446.

4. Cohen, S., Doyle, W.J., Skoner, D.P., Rabin, B.S. and Gwaltney, J.M. (1997). Jr. Social Ties and Susceptibility to the Common Cold. Journal of the American Medical Association, 277, 1940-1944.

5. Cristani, M. \&Murino, V. (2018). Chapter 10 - Person re-identification. Image and Video Processing and Analysis and Computer Vision. Academic Press Library in Signal Processing, Volume 6, 365-394.

6. Diedrichsen, J., Provost, S. \&Zareamoghaddam, H. (2016). On the distribution of cross-validated Mahalanobis distances. ArXiv:1607.01371v1[stat.AP] 5 jul 2016.

7. Etherington, T. R. (2019). Mahalanobis distances and ecological niche modelling: correcting a chi squared probability error. PeerJ7:e6678 http://doi.org/10.7717/peerj.6678

8. Goel, D., Subramanyam A. and Kamath, R. (2013). A Study on the Prevalence of Internet Addiction and Its Association with Psychopathology in Indian adolescents. Indian journal of Psychology, 2(55), 140143.

9. Gorain, S. C., Mondal, A., Ansary, K., and Saha. B. (2018) Social Isolation in Relation to Internet Usage and Stream of Study of Under Graduate Students.American Journal of Educational Research, 6(4), 361-364.

10. Hawkley, L.C., Burleson, M.H., Berntson, G.G. and Cacioppo, J.T. (2003). Loneliness in Everyday Life: Cardiovascular Activity, Psychosocial Context and Health Behaviors. Journal of Personality and Social Psychology, 85, 105-120.
11. Heikkinen, R., and Kauppinen, M. (2004). Depressive Symptoms in Late Life: A 10-year Follow-up. Archives of Gerontology and Geriatrics 38, 239-250.

12. Imani, M., (2019). Difference-based target detection using Mahalanobis distance and spectral angle. International Journal of Remote Sensing, 40(3), 811831.

13. Izanloo, M., and Goudarzi, C. (2011). The Relationship between Internet Addiction and Social Isolation and Quality of Social Interaction. First Congress of Social Psychology, 1 \& 2, 37-40.

14. John, O.P. and Srivastava, S. (1991). The Big Five Trait Taxonomy: History, Measurement and Theoretical Perspective, Guilford Press, New York.

15. Kelley, K. J. and Gruber, E. M. (2013). Problematic Internet use and physical health. Journal of Behavioral Addictions, 2(2), 108-112.

16. Kendell, J.J. (1998). Internet addiction on campus: the vulnerability of college students. CyberPsychology\& Behavior, 1, 11-17.

17. Kundu, M., Saha, B. \& Mondal, B C. (2015) "Adjustment of Undergraduate Students in Relation to Their Social Intelligence." American Journal of Educational Research, vol. 3, no. 11: 1198-1201. doi: 10.12691/education-3-11-8

18. Kuss, D. J., Griffiths, M. D., Karila, L., and Billieux, J. (2014). Internet Addiction: A Systematic Review of Epidemiological Research for the Last Decade. Current Pharmaceutical Design.

19. Mahalanobis, P.C. (1936). On the Generalized Distance in Statistics. Proceedings of the National Institute of Sciences of India, 2(1), 49 - 55.

20. Mahanti, J., Mondal, B.C. and Saha, B. (2016). Internet Dependency of Undergraduate Students: An Empirical Study, American International Journal of Research in Humanities, Arts and Social Sciences, 15(2), 171-174.

21. Malviya, A., Dixit, S., Shukla, H., Mishra, A., Jain, A. and Tripathi, A. (2014). A Study to Evaluate Internet Addiction Disorder among Students of a Medical College and Associated Hospital of Central India. National Journal of Community Medicine, 5, 93-95.

22. Marty Sapp, Ed. D., Festus E. Obiakor, Ph.D., Amanda J. Gregas, \&SteffanieScholze.(2007). Mahalanobis Distance: AMultivariate Measure of Effect in Hypnosis Research. Sleep and Hypnosis, January, 67-70.

23. Morrison, C. M. and Gore, H. (2010). The relationship between excessive Internet use and depression: a questionnaire-based study of 1,319 young people and adults. Psychopathology, 43(2), 121-126.

24. Muscanell N. L and Guadagno R. E. (2011). Make new friends or keep the old: Gender and personality differences in social networking use. Computers in Human Behavior, 28, 107-112.

25. Orzack, M. (1999). Computer addiction services. Published by $3 b$, http://www. Computer addiction.com

26. Paramanik, J., Saha, B. and Mondal, B. C. (2014). "Adjustment of Secondary School Students with Respect to Gender and Residence." American Journal of Educational Research, vol. 2, no. 12: 1138-1143. doi: 10.12691/education-2-12-2 


\section{EPRA International Journal of Research and Development (IJRD)}

27. Pressman, S.D., Cohen, S., Miller, G.E., Barkin, A., Rabin, B.S. and Treanor, J.J. (2005). Loneliness, Social Network Size, and Immune Response to Influenza Accination in College Freshmen. Health Psychology, 24, 297-306.

28. Rosenbaum, P. R. (2015). Observational Studies: Overview. James D. Wright (eds.), International Encyclopedia of the Social \&Behavioral Sciences (2nd ed. pp.107-112). Oxford: Elsevier.

29. Rubin, D. B. (1980).Bias Reduction Using Mahalanobis Metric Matching.Biometrics, 36, 293298.

30. Seif, G.M., Hoseini, H.M., and Sharifi, A.R. (2014). The Relationship between Internet Addiction and Social Support and Hopefulness. World Scientific News, 5, 1-11.

31. Sen, S. and Pal, I. (2020). Mahalanobis Distance: A Study on Achievement of Science and Mathematics. International Journal of Creative Research Thoughts. Vol. 8(7).

32. Swickert $R J$, Hittner $J$ B, Harris $J L$, Herring $J$ A. (2002). Relationships among Internet use, personality, and social support. Computers in Human Behavior, 18, 437-451.

33. Taylor, S.E., Repetti, R.L.and Seeman, T.E. (1979). Health psychology: What is an unhealthy environment and how does it get under the skin? Annual Review of Psychology, 48 (411-447).

34. Thoits, P. (1995). Stress, Coping and Social Support Processes: Where are We? What Next? Journal of Health and Social Behavior, 35, 53-79.

35. Tiwari, P. and Ruhela, S. (2012). Social Isolation and Depression among Adolescent: A Comparative Perspective. Paper presented at the 2nd International Conference on Social Science and Humanity, Singapore.

36. Toma, E. (2019). Analysis of motor fan radiated sound and vibration waveform by automatic Pattern recognition technique using "Mahalanobis distance". Journal of Industrial Engineering International, 15(1), 8192.

37. Tosun, L. P. and Lajunen, T. (2010). Does Internet use reflect your personality? Relationship between Eysen ck's personality dimensions and Internet use. Computers in Human Behavior, 26, 162-167.

38. Xiang, S., Nie, $F$ \& Zhang, C. (2008). Learning a Mahalanobis distance metric for dataclustering and classification. Pattern Recognition, 41, 3600 - 3612.

39. Yen, J.Y., Ko, C.H., Yen, C.F., Wu, H.Y. and Yang, M.J. (2007). The comorbid psychiatric symptoms of Internet addiction: attention deficit and hyperactivity disorder (ADHD), depression, social phobia, and hostility. Journal of Adolescent Health, 41(1), 93-98.

40. Yao, M. Z. and Zhong, Z.J. (2014). Loneliness, social contacts and Internet addiction: A cross-lagged panel study. Computers in Human Behavior, 30, 164- 170. 